\title{
Synthesis and Antimicrobial Activity of Pyrimidine Salts with Chloranilic and Picric Acids
}

\author{
C. Mallikarjunaswamy, ${ }^{1}$ D. G. Bhadregowda, ${ }^{1}$ and L. Mallesha ${ }^{2}$ \\ ${ }^{1}$ Department of Chemistry, Yuvaraja's College, University of Mysore, Mysore 570005, India \\ ${ }^{2}$ PG Department of Studies in Chemistry, JSS College of Arts, Commerce and Science, Ooty Road, Mysore 570025, India
}

Correspondence should be addressed to C. Mallikarjunaswamy; mallik.aanekere@gmail.com

Received 3 January 2012; Accepted 9 May 2012

Academic Editor: Julia Revuelta

Copyright ( 2013 C. Mallikarjunaswamy et al. This is an open access article distributed under the Creative Commons Attribution License, which permits unrestricted use, distribution, and reproduction in any medium, provided the original work is properly cited.

Pyrimidine salts such as 2-methyl-5-nitro-phenyl-(4-pyridin-3-yl-pyrimidin-2-yl)-amine (1) and 4-methyl-3-(4-pyridin-3-ylpyrimidin-2-yl-amino)-phenyl-amine (2) with chloranilic and picric acids were synthesized, and their in vitro antibacterial and antifungal activities were evaluated. The synthesized compounds were characterized by elemental analyses, UV-visible, FT-IR, and ${ }^{1} \mathrm{H}$ NMR spectral studies. Compound 2a exhibited good inhibition towards antimicrobial activity compared to the other compounds.

\section{Introduction}

The health problem demands to search and synthesize a new class of antimicrobial compounds which are effective against pathogenic microorganisms and develop resistance to the antibiotics used in the current regime [1]. The increasing resistance of human pathogens to current antimicrobial agents is a serious medical problem. During the 20th century, vaccines for bacterial toxins and many other common acute viral infections were developed and made widely available. The incidence of fungal infections has increased significantly in the past two decades [2]. The first-generation antifungal inhibitors of CYP51 have revolutionized the treatment of some serious fungal infections.

The pyrimidine derivatives possess a wide variety of potentially biological properties and are well known to work as herbicides [3,4] and pesticides [5]. Pyrimidine derivatives have been found to exhibit cytostatic [6-9] immunomodulating $[10,11]$ and antimicrobial properties [12-15]. Imatinib is a new anticancer agent, and it is currently marketed by as Gleevec. It is a protein tyrosine kinase inhibitor that inhibits the Bcr-Abl tyrosine kinase, the constitutive abnormal tyrosine kinase created by the Philadelphia chromosome abnormality in chronic myeloid leukemia (CML) [16]. It has also been found to be effective in the treatment of gastrointestinal stromal tumors (GISTs) [17]. This selective inhibition of Bcr-Abl kinase by imatinib has been a successful therapeutic strategy for CML because of the high efficacy and mild side effects of this compound $[18,19]$. Chloranilic acid (CA) and picric acid (PA) form salts with many organic compounds particularly with aromatic and aliphatic amines.

In connection with such studies, the present paper reports the salts formed by the reaction of 2-methyl-5-nitro-phenyl(4-pyridin-3-yl-pyrimidin-2-yl)-amine (1) and 4-methyl3-(4-pyridin-3-yl-pyrimidin-2-yl-amino)-phenyl-amine (2) with chloranilic and picric acids. These synthesized compounds were characterized by different spectral studies and biological results were reported in this paper. On the basis of their activity, these salts were identified as viable leads for further studies.

\section{Experimental}

All solvents and reagents were purchased from SigmaAldrich, India. Melting points were determined by Veego Melting Point VMP-III apparatus. Elemental analysis was carried out on Perkin Elmer 2400 elemental analyser. The UV-visible spectra were recorded on Analytikjena Specord $50 \mathrm{UV}$-vis spectrophotometer with quartz cell of $1.0 \mathrm{~cm}$ path 
length in DMSO. The infrared spectra on $\mathrm{KBr}$ pellets in the range of $4000-400 \mathrm{~cm}^{-1}$ were recorded on Jasco FT-IR 4100 series. FT-IR spectrophotometer provided with $\mathrm{KBr}$ optics. The NMR spectra were recorded using Bruker DRX 400 spectrometer at $400 \mathrm{MHz}$ for ${ }^{1} \mathrm{H}$ NMR with tetramethylsilane as the internal standard. Compounds $\mathbf{1} \mathbf{a}-\mathbf{b}$ and $\mathbf{2} \mathbf{a}-\mathbf{b}$ were synthesized by the method summarized in Scheme 1 .

2.1. General Procedure for the Synthesis of $1 \mathbf{a}$ and 2a. The reaction between imatinib intermediates $(1.0 \mathrm{eq})$ with chloranilic acid $(1.0 \mathrm{eq})$ in ethanol $(10 \mathrm{~mL})$. The reaction mixture was stirred at room temperature for $2 \mathrm{~h}$, where the solid precipitated after the reduction of the volume of the solvent. The separated precipitate was filtered off, washed several times with diethyl ether $(2 \times 0.5 \mathrm{~mL})$, and dried in vacuum over $\mathrm{CaCl}_{2}$.

2.2. 2-Methyl-5-nitro-phenyl-(4-pyridin-3-yl-pyrimidin-2-yl)ammonium-2,5-dichloro-4-hydroxy-3,6-dioxo-cyclohexa-1,4dienolate (1a). The general synthetic method described above afforded 1a, and the product obtained was violetcolored solid from 2-methyl-5-nitro-phenyl-(4-pyridin-3yl-pyrimidin-2-yl)-amine, 1 (0.31 g, $1 \mathrm{mmol})$ and chloranilic acid (CA) $(0.22 \mathrm{~g}, 1 \mathrm{mmol}) .{ }^{1} \mathrm{H}$ NMR (DMSO-d ${ }_{6}, 400 \mathrm{MHz}$ ) $\delta: 9.35(\mathrm{~s}, 1 \mathrm{H}$, pyridine- $\mathrm{H}), 9.30(\mathrm{~d}, 1 \mathrm{H}$, pyridine- $\mathrm{H}), 8.90$ (s, $1 \mathrm{H}, \mathrm{N}-\mathrm{H}), 8.77(\mathrm{~s}, 1 \mathrm{H}, \mathrm{Ar}-\mathrm{H}), 8.75(\mathrm{~d}, 1 \mathrm{H}$, pyrimidine- $\mathrm{H})$, $8.63\left(\mathrm{~s}, 2 \mathrm{H}, \mathrm{NH}_{2}\right), 7.90(\mathrm{~d}, 1 \mathrm{H}$, pyridine- $\mathrm{H}), 7.88(\mathrm{~d}, 1 \mathrm{H}$, Ar-H), $7.69(\mathrm{t}, 1 \mathrm{H}$, pyridine- $\mathrm{H}), 7.59(\mathrm{~d}, 1 \mathrm{H}, \mathrm{Ar}-\mathrm{H}), 7.49(\mathrm{~d}$, $1 \mathrm{H}$, pyrimidine- $\mathrm{H}), 2.40\left(\mathrm{~s}, 3 \mathrm{H}, \mathrm{CH}_{3}\right)$. FT-IR $\left(\mathrm{KBr}, \mathrm{cm}^{-1}\right)$ v: $3328(\mathrm{~N}-\mathrm{H}), 3108(\mathrm{Ar}-\mathrm{H}), 1672(\mathrm{C}=\mathrm{O}), 1578(\mathrm{C}=\mathrm{C})$, 1379 (C-C), 1287 (C-O), 1108 (C-N), 839 (C-Cl). Anal. Calcd. For $\mathrm{C}_{22} \mathrm{H}_{15} \mathrm{Cl}_{2} \mathrm{~N}_{5} \mathrm{O}_{6}$ (in \%): C-51.18, H-2.93, N-13.56. Found C-50.91, H-3.27, N-13.46\%.

2.3. 4-Methyl-3-(4-pyridin-3-yl-pyrimidin-2-ylamino)-phenyl-ammonium-2,5-dichloro-4-hydroxy-3,6-dioxo-cyclohexa1,4-dienolate (2a). The general synthetic method described above afforded $\mathbf{2 a}$, and the product obtained was violetcolored solid from 4-methyl-3-(4-pyridin-3-yl-pyrimidin-2ylamino)-phenyl-amine, $2(0.28 \mathrm{~g}, 1 \mathrm{mmol})$ and chloranilic acid (CA) $(0.22 \mathrm{~g}, 1 \mathrm{mmol}) .{ }^{1} \mathrm{H}$ NMR (DMSO-d 6 , $400 \mathrm{MHz}$ ) $\delta: 8.96(\mathrm{~s}, 1 \mathrm{H}, \mathrm{N}-\mathrm{H}), 8.81\left(\mathrm{~s}, 3 \mathrm{H}, \mathrm{NH}_{3}\right), 8.70(\mathrm{~s}, 1 \mathrm{H}$, pyridine$\mathrm{H}), 8.51$ (s, $1 \mathrm{H}, \mathrm{Ar}-\mathrm{H}), 8.43$ (d, $1 \mathrm{H}$, pyridine-H), 8.41 (d, $1 \mathrm{H}$, pyrimidine- $\mathrm{H}), 7.55(\mathrm{~d}, 1 \mathrm{H}$, pyridine $-\mathrm{H}), 7.51(\mathrm{t}, 1 \mathrm{H}$, pyridine- $\mathrm{H}), 7.46(\mathrm{~d}, 1 \mathrm{H}, \mathrm{Ar}-\mathrm{H}), 7.22(\mathrm{~d}, 1 \mathrm{H}, \mathrm{Ar}-\mathrm{H}), 6.84$ (d, $1 \mathrm{H}$, pyrimidine- $\mathrm{H}), 2.21\left(\mathrm{~s}, 3 \mathrm{H}, \mathrm{CH}_{3}\right)$. FT-IR $\left(\mathrm{KBr}, \mathrm{cm}^{-1}\right)$ $v: 3400\left(\stackrel{+}{\mathrm{N}_{3}}\right), 3163(\mathrm{~N}-\mathrm{H}), 3066(\mathrm{Ar}-\mathrm{H}), 1505(\mathrm{C}=\mathrm{O}), 1445$ $(\mathrm{C}=\mathrm{C}), 1203(\mathrm{C}-\mathrm{C}), 1129(\mathrm{C}-\mathrm{O}), 1040(\mathrm{C}-\mathrm{N}), 869(\mathrm{C}-\mathrm{Cl})$. Anal. Calcd. For $\mathrm{C}_{22} \mathrm{H}_{17} \mathrm{Cl}_{2} \mathrm{~N}_{5} \mathrm{O}_{4}$ (in \%): C-54.34, $\mathrm{H}-3.52$, N-14.40. Found C-53.96, H-3.20, N-14.13\%.

2.4. General Procedure for the Synthesis of $\mathbf{1} \mathbf{b}$ and $\mathbf{2} \mathbf{b}$. The reaction between imatinib and its intermediates $(1.0 \mathrm{eq})$ with picric acid $(1.0 \mathrm{eq})$ in ethanol $(10 \mathrm{~mL})$. The reaction mixture was stirred at room temperature for $1 \mathrm{~h}$, where the solid precipitated after the reduction of the volume of the solvent. The separated precipitate was filtered off, washed several times with diethyl ether $(2 \times 0.5 \mathrm{~mL})$, and dried in vacuum over $\mathrm{CaCl}_{2}$. The crude product was purified by crystallization from methanol solvent.

2.5. 2-Methyl-5-nitro-phenyl-(4-pyridin-3-yl-pyrimidin-2-yl)ammonium Picrate (1b). The general synthetic method described above afforded $\mathbf{1 b}$, and the product obtained was yellow colored solid from 2-methyl-5-nitro-phenyl(4-pyridin-3-yl-pyrimidin-2-yl)-amine, 1 ( $0.31 \mathrm{~g}, 1 \mathrm{mmol})$ and picric acid (PA) $(0.23 \mathrm{~g}, 1 \mathrm{mmol}) .{ }^{1} \mathrm{H}$ NMR (DMSO$\left.\mathrm{d}_{6}, 400 \mathrm{MHz}\right) \delta: 9.33(\mathrm{~s}, 1 \mathrm{H}$, pyridine- $\mathrm{H}), 9.28(\mathrm{~d}, 1 \mathrm{H}$, pyridine- $\mathrm{H}), 8.82(\mathrm{~s}, 1 \mathrm{H}, \mathrm{N}-\mathrm{H}), 8.73(\mathrm{~s}, 1 \mathrm{H}, \mathrm{Ar}-\mathrm{H}), 8.65$ (d, $1 \mathrm{H}$, pyrimidine- $\mathrm{H}), 8.55$ (s, $2 \mathrm{H}, \mathrm{C}_{6} \mathrm{H}_{2}$ of $\left.\mathrm{PA}\right), 7.90$ (d, $1 \mathrm{H}$, pyridine- $\mathrm{H}), 7.88(\mathrm{~d}, 1 \mathrm{H}, \mathrm{Ar}-\mathrm{H}), 7.78(\mathrm{t}, 1 \mathrm{H}$, pyridine$\mathrm{H}), 7.61(\mathrm{~d}, 1 \mathrm{H}, \mathrm{Ar}-\mathrm{H}), 7.49(\mathrm{~d}, 1 \mathrm{H}$, pyrimidine $-\mathrm{H}), 2.40(\mathrm{~s}$, $\left.3 \mathrm{H}, \mathrm{CH}_{3}\right)$. FT-IR $\left(\mathrm{KBr}, \mathrm{cm}^{-1}\right)$ v: $3401(\mathrm{~N}-\mathrm{H}), 3093(\mathrm{Ar}-\mathrm{H})$, $1407\left(\mathrm{NO}_{2}\right), 1346(\mathrm{C}-\mathrm{C}), 1083(\mathrm{C}-\mathrm{N})$. Anal. Calcd. For $\mathrm{C}_{22} \mathrm{H}_{16} \mathrm{~N}_{8} \mathrm{O}_{9}$ (in \%): C-49.26, H-3.01, N-20.89. Found C$48.89, \mathrm{H}-3.27, \mathrm{~N}-20.57 \%$.

2.6. 4-Methyl-3-(4-pyridin-3-yl-pyrimidin-2-ylamino)-phenyl-ammonium Picrate (2b). The general synthetic method described above afforded $\mathbf{2} \mathbf{b}$, and the product obtained was yellow-colored solid from 4-methyl-3-(4-pyridin-3-ylpyrimidin-2-ylamino)-phenyl-amine, $2(0.28 \mathrm{~g}, 1 \mathrm{mmol})$ and picric acid (PA) $(0.23 \mathrm{~g}, 1 \mathrm{mmol}) .{ }^{1} \mathrm{H}$ NMR (DMSO- $\mathrm{d}_{6}$, $400 \mathrm{MHz}) \delta: 9.27(\mathrm{~s}, 1 \mathrm{H}$, pyridine-H), $9.26(\mathrm{~s}, 1 \mathrm{H}, \mathrm{Ar}-\mathrm{H})$, $9.03(\mathrm{~s}, 1 \mathrm{H}, \mathrm{N}-\mathrm{H}), 8.90\left(\mathrm{~s}, 3 \mathrm{H}, \mathrm{NH}_{3}\right), 8.71(\mathrm{~d}, 1 \mathrm{H}$, pyridine$\mathrm{H}), 8.55(\mathrm{~s}, 2 \mathrm{H}, \mathrm{PA}), 8.53(\mathrm{~d}, 1 \mathrm{H}$, pyrimidine- $\mathrm{H}), 8.46(\mathrm{~d}$, $1 \mathrm{H}$, pyridine- $\mathrm{H}), 7.57(\mathrm{t}, 1 \mathrm{H}$, pyridine- $\mathrm{H}), 7.48-7.30(\mathrm{~d}, 2 \mathrm{H}$, Ar-H), $6.96\left(\mathrm{~d}, 1 \mathrm{H}\right.$, pyrimidine-H), $2.25\left(\mathrm{~s}, 3 \mathrm{H}, \mathrm{CH}_{3}\right)$. FT-IR

$\left(\mathrm{KBr}, \mathrm{cm}^{-1}\right)$ v: $3437\left(\stackrel{+}{\mathrm{NH}_{3}}\right), 3178(\mathrm{~N}-\mathrm{H}), 3068(\mathrm{Ar}-\mathrm{H})$, $1837(\mathrm{C}=\mathrm{C}), 1360(\mathrm{C}-\mathrm{C}), 1078(\mathrm{C}-\mathrm{N})$. Anal. Calcd. For $\mathrm{C}_{22} \mathrm{H}_{18} \mathrm{~N}_{8} \mathrm{O}_{7}$ (in \%): C-52.18, H-3.58, and N-22.13. Found C-51.95, H-3.93, N-22.46\%.

2.7. Antibacterial Activity. Antibacterial activity of the synthesized compounds was determined against Gram-positive bacteria (Bacillus subtilis and Staphylococcus aureus) and Gram-negative bacteria (Escherichia coli and Xanthomonas malvacearum ) in DMF by disc diffusion method on nutrient agar medium [20]. The sterile medium (nutrient agar medium, $15 \mathrm{~mL}$ ) in each Petri plates was uniformly smeared with cultures of Gram-positive and Gram-negative bacteria. Sterile discs of $10 \mathrm{~mm}$ diameter (Hi-Media) were made in each of the Petri plates, to which $50 \mu \mathrm{L}(1 \mathrm{mg} / \mathrm{mL}$, that is, $50 \mu \mathrm{g} / \mathrm{disc}$ ) of the different synthesized compounds were added. The treatments also included $50 \mu \mathrm{L}$ of DMF as negative, streptomycin $(1 \mathrm{mg} / \mathrm{mL} ; 10 \mu \mathrm{g} / \mathrm{disc})$ as positive control for comparison. For each treatment, three replicates were maintained. The plates were incubated at $37 \pm 2^{\circ} \mathrm{C}$ for $24 \mathrm{~h}$, and the size of the resulting zone of inhibition, if any, was determined.

2.8. Antifungal Activity. The synthesized compounds were screened for their antifungal activity against Fusarium oxysporum in DMF by poisoned food technique [21]. Potato 
<smiles>Cc1ccc([N+](=O)[O-])cc1Nc1nccc(-c2cccnc2)n1</smiles>

1

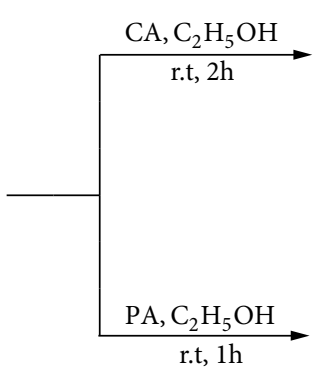<smiles>Cc1ccc([N+](=O)[O-])cc1Nc1nccc(-c2cccnc2)n1</smiles>

1a<smiles>Cc1ccc([N+](=O)[O-])cc1Nc1nccc(-c2cccnc2)n1</smiles>

$1 b$<smiles>Cc1ccc([NH3+])cc1Nc1nccc(-c2cccnc2)n1</smiles><smiles>Cc1ccc([NH3+])cc1Nc1nccc(-c2cccnc2)n1</smiles>

$2 b$

SCHEme 1: The illustration of the synthesis of $\mathbf{1 a - b}$ and $\mathbf{2} \mathbf{a}-\mathbf{b}$.

dextrose agar (PDA) media were prepared, and about $15 \mathrm{~mL}$ of PDA was poured into each Petri plate and allowed to solidify. $5 \mathrm{~mm}$ disc of seven-day-old culture of the test fungi was placed at the center of the Petri plates and incubated at $26^{\circ} \mathrm{C}$ for 7 days. After incubation, the percentage inhibition was measured and three replicates were maintained for each treatment. Nystatin was used as standard. All the synthesized compounds, and nystatin were tested (at the dosage of $500 \mu \mathrm{L}$ of the compounds/Petri plate, where concentration was $0.1 \mathrm{mg} / \mathrm{mL}$ ) by poisoned food technique.

\section{Results and Discussion}

The elemental analyses data showed good agreement between the experimentally determined values and the theoretically calculated values within the limits of permissible error. New bands were detected in the UV-visible spectra of the salts. These bands are not exhibited by either donor or acceptors alone. The appearance of longer wavelength absorption band in the visible region in UV-visible spectrum owing to the charge transfer transition confirms the formation of products. Yield, melting point, and UV-visible spectral data of the synthesized salts are listed in Table 1.

The infrared spectra of the molecular salts of $\mathrm{CA}$ and PA with donors indicate that $v(\mathrm{C}-\mathrm{Cl})$ of $\mathrm{CA}$ and $v\left(\mathrm{NO}_{2}\right)$ of $\mathrm{PA}$ are shifted to lower wavenumber values. The stretching
TABLE 1: Physical characterization of the synthesized compounds.

\begin{tabular}{lccc}
\hline Compound & Yield $(\%)$ & M. P $\left({ }^{\circ} \mathrm{C}\right)$ & UV-visible $\left(\lambda_{\max }\right)$ \\
\hline 1a & 60 & $218-220$ & 530 \\
1b & 56 & $174-176$ & 530 \\
2a & 61 & $198-202$ & 420 \\
2b & 64 & $200-203$ & 455 \\
\hline
\end{tabular}

frequency of $\mathrm{C}=\mathrm{O}$ bond of the acceptor displays a shift to a higher wavenumber values. Infrared spectra of the synthesized complexes show a strong band, indicating $\stackrel{+}{\mathrm{N}}-\mathrm{H} \cdots \mathrm{O}^{-}$ stretching vibration of the intermolecular hydrogen bond.

Compounds showed signals around 2.1-2.9 ppm and in the region 6.8-9.4 ppm due to methyl group and aromatic group of the synthesized salts. New signals are observed at 8.81-8.90 ppm assigned to $\stackrel{+}{\mathrm{N}}-\mathrm{H}$ proton. The $\mathrm{O}-\mathrm{H}$ signals of the free CA and free PA were disappeared on salt formation. These data is agreed quite well with the elemental analyses, UV-visible and FT-IR studies.

3.1. Antibacterial Activity. The investigation of antibacterial screening data revealed that synthesized salts was evaluated and compared with standard drug streptomycin. Compounds $\mathbf{1 a}, \mathbf{1} \mathbf{b}$, and $\mathbf{2} \mathbf{b}$ showed less inhibitory activity against 
TABLE 2: In vitro antibacterial and antifungal activities of synthesized compounds.

\begin{tabular}{lccccc}
\hline \multirow{2}{*}{ Compounds } & \multicolumn{4}{c}{ Diameter of inhibition zone $(\mathrm{mm})$ \% inhibition } \\
& B. subtilis & S. aureus & X. malvacearum & E. coli & 13 \\
1a & 11 & 12 & 13 & 12 & 43.0 \\
1b & 11 & 11 & 12 & 14 & 41.1 \\
2a & 13 & 15 & 16 & 14 & 56.4 \\
2b & 11 & 12 & 13 & 19 & 48.3 \\
Streptomycin & 18 & 20 & - & - & 85.2 \\
Nystatin & - & - & & & - \\
\hline
\end{tabular}

Bacillus subtilis, Staphylococcus aureus, and Escherichia coli. Compound 2a exhibited good activity with the zone of inhibition in the range of $16 \mathrm{~mm}$ against pathogenic bacterial strain.

3.2. Antifungal Activity. The antifungal activity of synthesized salts were evaluated and compared with standard drug nystatin. All the synthesized salts showed moderate inhibitory activity compared with standard drug. Compound 2a showed good antifungal activity with the $56.4 \%$ inhibition against $F$. oxysporum, compared with $\mathbf{2 b}, \mathbf{1 a}$, and $\mathbf{1 b}$. Among the synthesized salts, inhibitory activity is in the order of $\mathbf{2 a}>\mathbf{2} \mathbf{b}>\mathbf{1 a}>\mathbf{1 b}>$ against tested fungi. The compound 2a exhibited good activity against fungal strain. The salts of imatinib and its intermediates with chloranilic acid are more antimicrobial activity compared with salts of picric acid. Antimicrobial screening results of the tested salts are shown in Table 2.

\section{Conclusion}

In conclusion, salts of pyrimidines with chloranilic and picric acids were synthesized in good yield, characterized by different spectral studies, and their antimicrobial activity has been evaluated. Compound $\mathbf{2 a}$ demonstrated good inhibition against all the strains tested. It should be noted that compound 2a demonstrated better inhibition compared to other compounds against bacterial and fungal strains tested.

\section{Conflict of Interests}

The authors report no conflict of interests. The authors alone are responsible for the content and writing of the paper.

\section{Acknowledgments}

The authors thank D. Rakshith, Department of Microbiology, University of Mysore, India, for carrying out antimicrobial studies.

\section{References}

[1] M. Koca, S. Servi, C. Kirilmis et al., "Synthesis and antimicrobial activity of some novel derivatives of benzofuran: part 1. Synthesis and antimicrobial activity of (benzofuran-2-yl)(3- phenyl- 3-methylcyclobutyl) ketoxime derivatives," European Journal of Medicinal Chemistry, vol. 40, no. 12, pp. 1351-1358, 2005.

[2] D. A. Enoch, H. A. Ludlam, and N. M. Brown, "Invasive fungal infections: a review of epidemiology and management options," Journal of Medical Microbiology, vol. 55, no. 7, pp. 809-818, 2006.

[3] E. Josef, "Synthesis and herbicidal activity of $2 \mathrm{H}-1,2,4-$ thiadiazole[2,3-a]pyrimidines," HU Patent, A01N47/30, 46839, 1988, 12, 28.

[4] R. Butnariu, I. M. Risca, M. Caprosu, G. Drochioiu, and I. Mangalagiu, "Biological activity of some new pyridazine derivatives in wheat germination experiments," Romanian Biotechnological Letters, vol. 13, pp. 3837-3842, 2008.

[5] K. Takashi and I. Hajime, "Pyrimidine derivatives and herbicides containing the same," US Patent, A01N43/54, 2004092402, 2004, 5, 13.

[6] Z. Machoo and J. Cieplik, "Synthesis and antineoplastic effects of fluro[3,4-d]pyrimidine derivatives," Polish Journal of Pharmacology and Pharmacy, vol. 40, article 201, 1988.

[7] N. R. Mohamed, M. M. T. El-Saidi, Y. M. Ali, and M. H. Elnagdi, "Utility of 6-amino-2-thiouracil as a precursor for the synthesis of pyrido[2,3-d]pyrimidines and their in vitro and in vivo biological evaluation," Scientia Pharmaceutica, vol. 75, no. 1, pp. 9-28, 2007.

[8] A. M. V. Zbancioc, G. N. Zbancioc, C. Tanase, A. Miron, C. Ursu, and I. I. Mangalagiu, "Design, synthesis and in vitro anticancer activity of a new class of bifunctional DNA intercalators," Letters in Drug Design and Discovery, vol. 7, no. 9, pp. 644-649, 2010.

[9] M. C. C. Luca, V. V. Tura, and I. I. Mangalagiu, "Considerations concerning design and mechanism of action of a new class of anticancer dual DNA intercalators," Medical Hypotheses, vol. 75, no. 6, pp. 627-629, 2010.

[10] J. Cieplik, Z. Machon, M. Zimecki, and Z. Wieczorek, "Synthesis and immunomodulatory activity of 6-methyl-2-phenyl-5substituted pyrimidines," Farmaco, vol. 50, no. 2, pp. 131-136, 1995.

[11] J. Pluta, M. Flendrich, and J. Cieplik, "Synthesis and biological activity of some pyrimidine derivatives," Bollettino Chimico Farmaceutico, vol. 135, no. 8, pp. 459-464, 1996.

[12] Y. A. Mostafa, M. A. Husein, A. A. Radwan, and A. H. Kfafy, "Synthesis and antimicrobial activity of certain new 1,2,4triazolo(1,5-a)pyrimidine derivatives," Archives of Pharmacal Research, vol. 31, no. 3, article 279, 2008.

[13] G. T. Kim, R. J. Ryu, S. Lee, H. Youn, Y. R. Cho, and H. Y. Joo, "Characterization of a novel amylolytic enzyme encoded by a gene from a soil-derived metagenomic library," Antibiotics Journal of Japanese Research, vol. 34, article 468, 2004. 
[14] C. Moldoveanu and I. I. Mangalagiu, "4-Methyl- and 4(halophenyl)pyrimidinium (4-halobenzoyl)methylides. Correlation of structure, stability, reactivity, and biological activity," Helvetica Chimica Acta, vol. 88, no. 10, pp. 2747-2756, 2005.

[15] M. Ungureanu, C. C. Moldoveanu, A. Poeata, G. Drochioiu, M. Petrovanu, and I. I. Mangalagiu, "New pyrimidine derivatives endowed with antibacterial activity or fongistatic in vitro," Annales Pharmaceutiques Francaises, vol. 64, no. 4, pp. 287-288, 2006.

[16] R. Capdeville, E. Buchdunger, J. Zimmermann, and A. Matter, "Glivec (ST1571, imatinib), a rationally developed, targeted anticancer drug," Nature Reviews Drug Discovery, vol. 1, no. 7, pp. 493-502, 2002.

[17] G. D. Demetri, M. Von Mehren, C. D. Blanke et al., "Efficacy and safety of imatinib mesylate in advanced gastrointestinal stromal tumors," The New England Journal of Medicine, vol. 347, no. 7, pp. 472-480, 2002.

[18] M. Kalaycio, "A new standard treatment for chronic myelogenous leukemia," Current Hematology Reports, vol. 3, article 37, 2004.

[19] K. Peggs and S. Mackinnon, "Imatinib mesylate-the new gold standard for treatment of chronic myeloid leukemia," The New England Journal of Medicine, vol. 348, no. 11, pp. 1048-1050, 2003.

[20] A. W. Bauer, W. M. Kirby, J. C. Sherris, and M. Turck, "Antibiotic susceptibility testing by a standardized single disk method," American Journal of Clinical Pathology, vol. 45, no. 4, pp. 493-496, 1966.

[21] S. Satish, D. C. Mohana, M. P. Raghavendra, and K. A. Raveesha, "Antifungal activity of some plant extracts against important seed borne pathogens of Aspergillus sp." Journal of Agricultural Technology, vol. 3, pp. 109-119, 2007. 

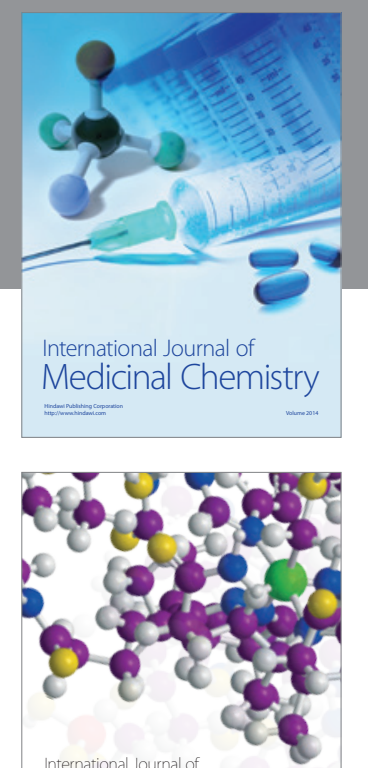

\section{Carbohydrate} Chemistry

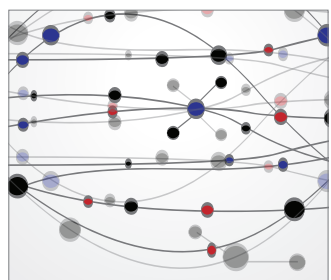

The Scientific World Journal
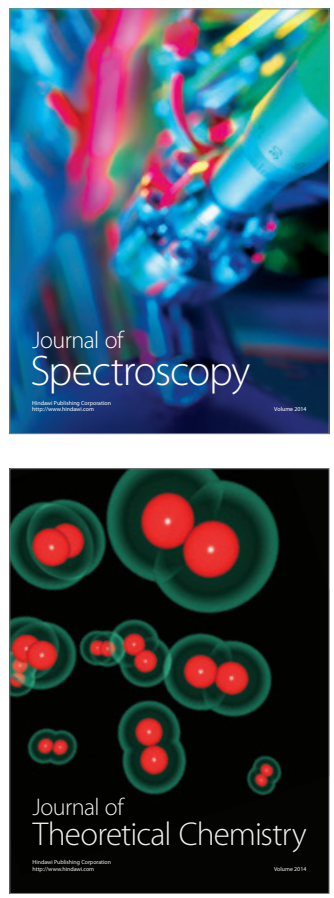
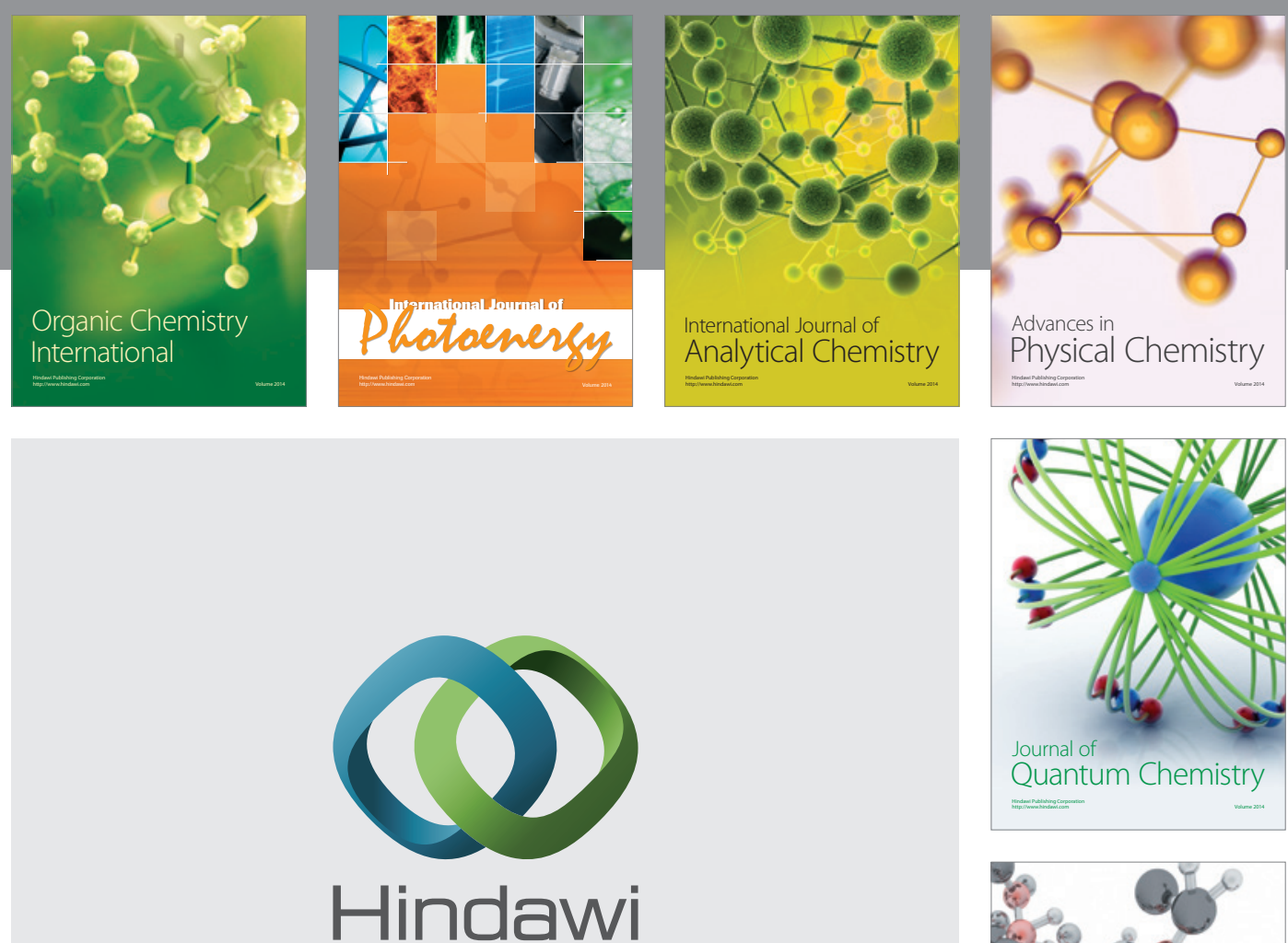

Submit your manuscripts at

http://www.hindawi.com

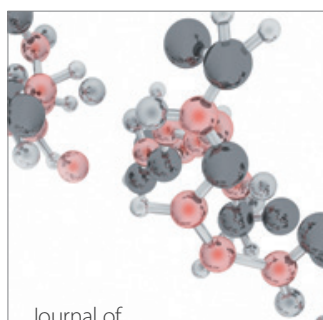

Analytical Methods

in Chemistry

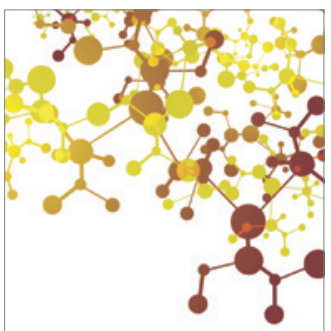

Journal of

Applied Chemistry

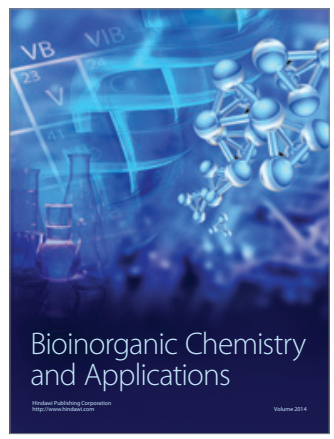

Inorganic Chemistry
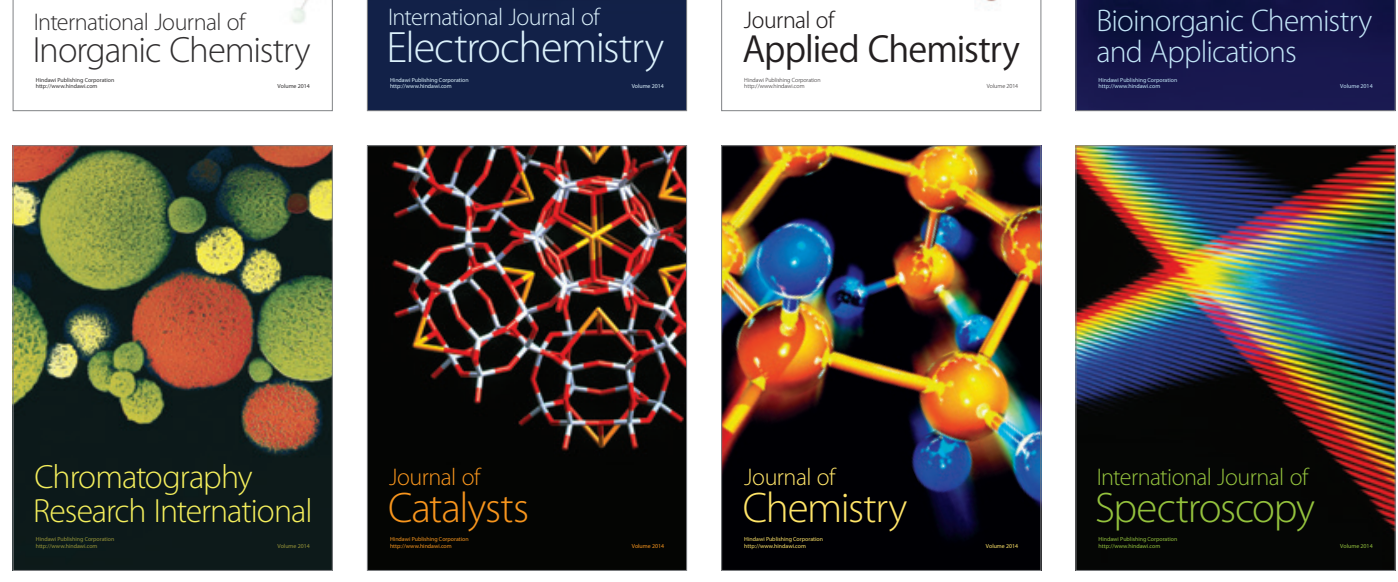